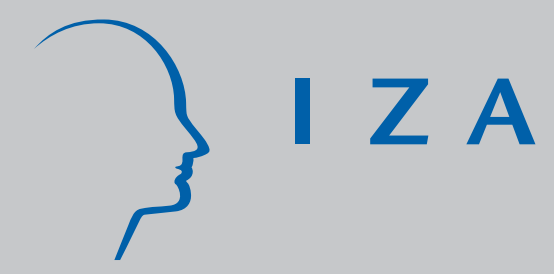

IZA DP No. 1464

Determinants of Union Membership in $18 \mathrm{EU}$

Countries: Evidence from Micro Data, 2002/03

Claus Schnabel

J oachim Wagner

J anuary 2005 


\title{
Determinants of Union Membership in 18 EU Countries: Evidence from Micro Data, 2002/03
}

\author{
Claus Schnabel \\ University of Erlangen-Nuremberg \\ Joachim Wagner \\ University of Lueneburg \\ and IZA Bonn
}
Discussion Paper No. 1464
January 2005

IZA

P.O. Box 7240

53072 Bonn

Germany

Phone: +49-228-3894-0

Fax: +49-228-3894-180

Email: iza@iza.org

\begin{abstract}
Any opinions expressed here are those of the author(s) and not those of the institute. Research disseminated by IZA may include views on policy, but the institute itself takes no institutional policy positions.

The Institute for the Study of Labor (IZA) in Bonn is a local and virtual international research center and a place of communication between science, politics and business. IZA is an independent nonprofit company supported by Deutsche Post World Net. The center is associated with the University of Bonn and offers a stimulating research environment through its research networks, research support, and visitors and doctoral programs. IZA engages in (i) original and internationally competitive research in all fields of labor economics, (ii) development of policy concepts, and (iii) dissemination of research results and concepts to the interested public.
\end{abstract}

IZA Discussion Papers often represent preliminary work and are circulated to encourage discussion. Citation of such a paper should account for its provisional character. A revised version may be available directly from the author. 
IZA Discussion Paper No. 1464

January 2005

\section{ABSTRACT}

\section{Determinants of Union Membership in 18 EU Countries: Evidence from Micro Data, 2002/03*}

Using representative individual-level data from the first round of the European Social Survey fielded in 2002/03, this paper provides an empirical analysis of unionization in 18 countries of the European Union. We show that union density varies considerably in Europe, ranging from 84 per cent in Denmark to 11 per cent in Portugal. Estimating identical models for each country, we find that individuals' probability of union membership is significantly affected by their personal characteristics, their attitudes and the characteristics of their workplace, whereas social factors seem to play a minor role. The presence of a union at the workplace and employees' attitudes concerning strong unions are the two variables with the most widespread effects on unionization.

JEL Classification: $\quad \mathbf{5} 1$

Keywords: union membership, union density, Europe

Corresponding author:

Joachim Wagner

Institute of Economics

University of Lueneburg

Campus 4.210

21332 Lueneburg

Germany

Email: wagner@uni-lueneburg.de

\footnotetext{
* The authors would like to thank Alex Bryson for helpful comments and suggestions on a previous version of this paper. The usual disclaimer applies.
} 


\section{INTRODUCTION}

In many western countries, trade unions find it more and more difficult to attract and to keep members. Calculations by Visser (2003) show that between 1985 and 1997 aggregate union membership in the European Union (EU 15) fell by 8 per cent and aggregate union density by about 8 percentage points. ${ }^{1}$ However, these aggregate trends (also identified by Checchi and Lucifora 2002) mask substantial differences between countries. While in some countries unions have experienced decline, in others they have been able to grow. The levels of union density also differ markedly between countries in Europe. These differences matter because they may influence the political and economic power of unions in their home countries as well as at EU level.

There exists a substantial empirical literature on the determinants of union membership and density which uses aggregate time-series analyses as well as individual-level cross-sectional analyses (see the surveys by Riley 1997 and Schnabel 2003). However, most of these studies concentrate on a single country. ${ }^{2}$ Cross-national variations in unionization have been analyzed in a few studies that make use of three empirical approaches: They either provide cross-sectional estimations of union density across industrialized countries at a certain date (see, for example, Western 1997, Ebbinghaus and Visser 1999), they compare changes in union membership or density in these countries over time (Ebbinghaus and Visser 1999, Blaschke 2000, Visser 2002), or they analyze a pooled time-series cross-section panel data set (Calmfors et al. 2001, Checchi and Visser 2001, Checchi and Lucifora 2002). The main focus of most of these cross-national studies is on institutional factors (such as union-affiliated unemployment insurance and workplace representation) or on structural change, and all of them use aggregate data.

To the best of our knowledge, however, no study seems to exist that makes use of similar individual-level data of employees in several countries and that estimates identical models of union membership (and calculates union density figures) for these countries. This paper attempts to fill this gap in the literature by using a new large-scale data set for European countries, the European Social Survey. It will be

\footnotetext{
Similar trends can be found in North America, Oceania, and in the transition countries of Eastern Europe; see Visser (2003).

2 A recent exception is the comparative analysis of youth-adult differences in unionization of American, British and Canadian workers by Bryson et al. (2005).
} 
interesting to see whether the same (groups of) variables are able to explain union membership in different countries and which variables are most important for unionization.

The structure of the paper is as follows: section 2 explains the data used and calculates union density figures for EU countries. A brief overview of various theoretical models from economics and social psychology that try to explain unionization is provided in section 3. Section 4 presents the results of our empirical investigation and identifies the main determinants of union membership in EU countries. The impact of key variables is simulated in section 5 , and section 6 concludes.

\section{UNION DENSITY IN EU COUNTRIES}

Most of the existing figures on union density in Europe are based on membership data provided by the unions, although for some countries labour force surveys also offer some information (see Visser 2003, Lesch 2004). The data used in this study were taken from the first round of the European Social Survey (ESS) fielded in 2002/03 (Jowell et al. 2003). This cross-section survey is covering 22 countries (Austria, Belgium, Czech Republic, Denmark, Finland, France, Germany, Greece, Hungary, Ireland, Israel, Italy, Luxembourg, Netherlands, Norway, Poland, Portugal, Slovenia, Spain, Sweden, Switzerland, and the United Kingdom). The universe are all persons aged 15 and above resident within private households, regardless of their nationality, citizenship, language or legal status. The survey involves strict random probability sampling, a minimum target response rate of 70 per cent and rigorous translation protocols; data are collected in face-to-face interviews. ${ }^{3}$ Given our focus on countries that are (or have recently become) members of the European Union we exclude Israel, Norway and Switzerland. Furthermore, we cannot use the data for the Czech Republic due to missing information on the union membership status.

A great advantage of the ESS data for our effort lies in the ex-ante coordination of the questionnaire used among the teams involved in the various country surveys. Although the sample size varies considerably between countries (see Table 1),

3 The data and information about the ESS are available from the ESS home site located at NSD Norwegian Social Science Data Services (http://ess.nsd.uib.no).For our study we use version ESS1 edition 05.0 released June 17, 2004. To facilitate replication and extensions of our results the Stata do-files used are available on request from the second author. 
these data should be a much better basis for cross-country comparisons than data from national sources. The interviewees were asked whether they were a member of a trade union at the time of the interview or in the last 12 months (see ESS question E3a for details). Those who answered this question in the affirmative are coded as union members. ${ }^{4}$ Restricting the sample to employees only (and thus avoiding the problem that union figures usually also include data on retired and unemployed members) we are able to calculate (net) density rates defined as the percentage of union members among the employees in each country.

(Table 1 about here)

Table 1 presents information on union density available from our sample that is based on weighted data. As can be seen from the point estimates in the first column, in 2002/03 union density figures varied considerably in Europe, ranging from about 11 per cent in Portugal to almost 84 per cent in Denmark. ${ }^{5}$ In general the Nordic countries record the highest union densities whereas the Mediterranean countries are at the bottom of the distribution. In many countries the point estimates of average density differ between men and women, but the 95 per cent confidence intervals are quite large and there is no clear picture across countries as to whether male or female employees are more likely to be union members. The same can be said for blue collar and white collar workers. This may be a bit surprising given the long-time belief that men and blue collar workers are the backbone of the unions, and it will be interesting to see whether similar effects also show up in multivariate analyses.

\section{THEORETICAL EXPLANATIONS OF UNION MEMBERSHIP}

Union membership and its determinants have been studied from various perspectives by economists, sociologists, psychologists and political scientists (see Schnabel 2003 for a recent survey), and it has proved difficult or even impossible to identify a standard model of unionization. The traditional economic approach has analyzed the forces that influence union membership within a

4 Note that in question F28 the interviewees were asked "Are you or have you ever been a member of a trade union or similar organization?", and one category is "Yes, currently". However, given that we do not know what the interviewees consider as a "similar organization" we did not use the information based on this question.

5 The figures in Table 1 are reasonably close to those based on labour force surveys for a few countries in 1997-99 presented by Visser (2003). They differ in an unsystematic way from the figures presented by Visser (2003) and by Lesch (2004) that were calculated from other data using different methods. 
conventional framework of demand and supply which can be traced back to Berkowitz (1954) and Pencavel (1971). Union membership is considered as though it were an asset in the portfolio of a utility-maximizing worker that provides a flow of services, which are private and/or collective goods. Demand for union membership depends negatively on its costs relative to the price of other goods and assets, whereas income or wealth should influence union membership positively if union services are a normal good. The larger the monetary and nonmonetary benefits of union representation are, the more likely are employees to join a union. In contrast, the lower the cost of substitute services (such as social welfare benefits), the lower demand for union services should be. Finally, individuals' taste for unionism can affect the demand for union membership. This variable is meant to reflect workers' attitudes and preferences, ideological motives, social pressure and customs, and related non-economic variables stressed by other disciplines of social science.

Although unions may not be typical profit maximizers, they face a binding budget constraint in that they must fund union organizing and services, which means that they must pay attention to revenues and (opportunity) costs. Therefore the supply of union services depends positively on revenues whereas the costs of union organizing and the costs of servicing existing members both affect supply negatively. Organizing and servicing costs are likely to have a fixed-cost component so that collective bargaining exhibits decreasing unit costs with respect to membership, and unionism is therefore less likely in small firms. Both the costs of organizing and of servicing will be affected by employers' attitudes toward unions and collective bargaining, and they can be influenced substantially by the legal structure within which unions may operate. Furthermore union goals (such as maximizing membership or a certain utility function) may affect the supply of union services in various ways.

Empirical studies generally estimate some variant of a reduced-form equation combining the supply and demand functions. Since most of the variables sketched above cannot be measured directly, they are often substituted for by proxy variables (such as firm size, industry affiliation and personal characteristics). However, these variables are likely to affect unionism through more than one channel, so that interpretation is difficult. In addition to measurement problems in the explanatory variables of the reduced-form equation, the amount of union services is also not directly observed. Assuming that the level of services is proportional to the level of unionization, direct measures of union membership, union density or bargaining coverage can be used to proxy union services. 
A major problem of this sort of cost-benefit analysis is that it does not pay enough attention to an important challenge trade unions face in most countries, namely the free-rider problem. Many of the services unions provide - such as higher wages and better working conditions - accrue both to union members and non-members in the workplace. These services can be seen as public or collective goods since they are non-rival in consumption, and low-cost exclusion of non-members is not possible. Hence an individual has a free-rider incentive not to join the union. The key problem for economists is to explain why any individual would join a union when dues are costly and when the benefits apply to all workers regardless of their union status.

A prominent explanation of why large groups providing collective goods such as trade unions manage to exist despite the free-rider problem stems from Olson (1965) who argued that a large group can only have formed for two reasons: Either because membership is compulsory or because the group offers selective incentives in the form of private goods and services available only to its members (with ancillary provision of the collective good as a "byproduct"). As regards unions, Olson (1965: 75) thought that "[i]n most cases it is compulsory membership and coercive picket lines that are the source of the union's membership". In European countries, however, "closed shops" (in which union membership is a condition of employment) are either illegal or are rarely found anymore, and the widespread presence of "open shop" unions (where membership is voluntary) suggests that selective incentives such as strike pay and legal support available to members may be more important for joining a union. ${ }^{6}$

In addition to such material selective incentives, Booth (1985) has suggested to interpret the incentive private good as being the "reputation" utility that derives from complying with a social custom of union membership. This idea stems from Akerlof (1980) and takes up an argument commonly put forward by sociologists and psychologists, namely that within a community there is a set of rules and customs that are obeyed by individuals because of the sanction of a loss of reputation if the custom should be disobeyed. In the context of union membership, the social custom can be thought of as urging workers not to free-ride. Following

6 Booth and Chatterji (1995) develop a theoretical model of the simultaneous determination of union wages and membership which points to the existence of excludable private goods such as grievance procedures, influence over manning arrangements or representation by the union as an important factor motivating workers to join unions in the absence of coercive closed shop rules. In models by Moreton (1998) and by Jones and McKenna (1994) greater job security for union members acts as a selective incentive to join the union. Bulkley and Myles (2001) argue that joining a union instead of free-riding may be rational if it enables individuals to influence union bargaining goals and thus their own employment probability. 
social custom theory, Booth (1985) and Naylor (1990) have proposed models in which it is assumed that workers directly derive utility from the reputation effect of belonging to a union, and which show that a union can exist despite the free-rider problem if it achieves a minimum critical density. In the social custom approach, the decision to join is interdependent and - contrary to the Olson (1965) free-rider paradox - workers may be more prepared to join a union if others are joining. ${ }^{7}$

Within this framework, Naylor and Cripps (1993) have shown that when workers' tastes are heterogeneous with respect to their sensitivity to reputation, stable intermediate union density is a possible equilibrium outcome. They provide an explanation of voluntary membership of the open shop trade union in which the union density level is likely to increase as a result of a reduction in union membership costs, an increase in strike pay or an increase in individuals' sensitivity to the social custom of union membership and the associated solidarity effects. ${ }^{8}$ Furthermore, Booth and Chatterji (1993) have provided a model of union membership and wage determination which predicts that the open shop union is viable only after membership has achieved a minimum critical density, and wages are at a sufficient level to support this.

Social custom models indicate that in addition to pure economic reasoning, social and psychological factors may also contribute to explaining the level and development of union membership. Within the social psychology, four theoretical and partly overlapping approaches to trade union participation can be distinguished, namely frustration-aggression theory, attribution theory, rationalchoice theory and the interactionist approach (see Klandermans 1986, Frege 1996)..$^{9}$

The frustration-aggression approach explains union membership as a result of individuals' frustration, dissatisfaction or alienation in their work situation (and membership resignation in terms of frustration with union policies). However,

7 Naylor (1990) demonstrates the formal equivalence of the Booth (1985) model and the "critical mass" or "tipping" models developed by Schelling (1978); see also the "resource mobilization" approach by Klandermans (1984).

8 Extensions of the social custom model taking into account employer behaviour have been proposed by Naylor and Raaum (1993) and by Corneo (1995). They show that a stable long-run equilibrium may exist, in which strong unions persist in spite of management opposition.

9 A short overview of psychological and socio-political theories of union membership and participation can also be found in Guest and Dewe (1988). Earlier contributions from sociologists and political scientists - stressing the importance of factors such as class consciousness, values, modes of production, the composition of the workforce, the political climate, the role of government incomes policies, and the centralisation and cohesiveness of the labour movement - include Streeck (1981) and Beyme (1981). 
dissatisfaction "is neither a necessary nor a sufficient condition for participation" (Klandermans 1986: 199). Attribution theory deals with the ways in which people try to explain events in their own social environment (see, e.g., Kelley and Michela 1980). People are assumed to make judgements about the causes or reasons of events or individuals' behaviour, and these explanations ("attributions") have consequences for their future behaviour. If, for instance, problems at the workplace are attributed to external (i.e. non-personal) but controllable factors, collective action and union participation may be one consequence.

Rational-choice theory interprets unionization as the outcome of a process of weighing the costs and benefits of participation (a prominent example is Crouch 1982). Of course, such an approach also underlies economic theories of unionization, but economists often pay attention only to individual, selective costs and benefits (without asking whether the actors really perceive the underlying net benefit). In contrast, social scientists try to take a broader view and point out that the unionization decision can also be influenced by collective, social and ideological motives, which may be difficult to measure. The balance of perceived costs and benefits, combined with expectations about the degree to which the union will be able to realize these motives, determine the actual decision to be a union member.

In the interactionist approach union participation is inextricably bound up with group culture, and an individual's decision to join a union is strongly influenced by his social context, i.e. his living and working environment (see also social identity theory, e.g. Tajfel 1982). Concerning the working environment, the prevailing union density in an individual's establishment or industry and the contact with the union at the workplace may play a role. Concerning the living environment, tradition and prevailing opinions within someone's group are important because here general beliefs are formed about unions even before the employment relationship is entered into. Starting with Booth (1985) this line of reasoning has been incorporated into the social custom models of union membership discussed above which in some sense blend interactionist and rational-choice explanations.

To a certain degree, social scientists provide other explanations or emphasize different determinants of unionization than economists. Some of these factors can be incorporated in the economist's supply-demand and cost-benefit framework discussed above whereas others are more difficult to operationalize. Empirical studies of the determinants of union membership usually take an eclectic approach and combine economic as well as socio-political hypotheses and 
explanations. Surveys of the international empirical evidence are provided, inter alia, by Chaison and Rose (1991), Wheeler and McClendon (1991), Riley (1997) and Schnabel (2003). They show that according to time-series studies business cycle factors and structural developments play a significant role in explaining union membership trends and that cross-sectional analyzes at the level of individuals have identified a number of personal, occupational and firm characteristics, attitudes and social variables which are associated with the unionization decision in different countries. While time-series analysis is not feasible since our data cover just one wave of the ESS, the latter approach will be pursued now.

\section{EMPIRICAL ANALYSES OF THE FACTORS ASSOCIATED WITH UNION MEMBERSHIP}

The ESS data described in section 2 allow us to investigate the factors associated with union membership because they include information on a number of potential covariates such as personal and occupational characteristics, family background, attitudes, and union organization at the workplace. They can be used to estimate identically specified empirical models for each of the 18 countries included in our study and they should provide a much better basis for cross-country comparisons than data from national surveys. Since the dependent variable in our investigation is a 1/0-dummy variable indicating whether an employee is a union member or not, a probit analysis (estimating the probability of union membership) is appropriate.

The explanatory variables used are listed and grouped in Table 2. The first group of variables contains a number of personal characteristics such as gender, age, education and occupation that have been found to be systematically related to union membership in cross-sectional studies in many countries (see the surveys by Riley 1997 and Schnabel 2003). The descriptive statistics in Table 1 show that in 10 of the 18 countries investigated the union density of men is higher than that of women. This difference has traditionally been interpreted as a reflection of men's greater degree of attachment to the labour force which would increase the benefits of unionization both from the point of view of employees and of unions. ${ }^{10} \mathrm{~A}$ similar cost-benefit reasoning applies to full-time workers, so that we include dummy variables for gender and full-time working in the analysis. The occupational status of employees is represented by a dummy variable for blue

10 Visser (2003: 397), however, notes that "since the early 1980s, nearly all of the growth in membership in EU unions has come from women" and that "the gender gap in unionization is narrowing", so that this traditional hypothesis may not hold anymore. 
collar workers. Economic and rational-choice considerations predict that blue collar workers should have a higher probability of being union members since they have rather homogeneous preferences and working conditions which make them easier to organize than white collar workers. Interestingly, however, according to the descriptive evidence in Table 1 only in 9 of the 18 countries investigated union density is higher for blue collar workers, whereas in the other 9 countries it is lower.

An age variable is included in the analysis in order to test the hypothesis that younger workers are less likely to be union members due to their different socialization resulting in lower identification with unions. Since the relationship between age and unionization might be concave (increasing at a decreasing rate and possibly falling at the end), we include both age and its square in our estimations. We further employ two dummy variables that take on the value of 1 if employees' highest educational level completed is below the upper secondary level and if they have completed the second stage of tertiary education, respectively. For both groups of lowly and highly educated employees we expect a lower probability of unionization than for our reference group with medium-level education because recruitment costs should be higher for these groups than for the (rather homogeneous) group of skilled workers traditionally represented by the trade unions. Furthermore, more educated employees usually have greater individual bargaining power (and thus a lesser need for collective voice), and sometimes they identify more with management than with the labour movement. Lowly skilled workers may be more union-friendly, but since they often experience a higher labour market fluctuation, neither they nor the unions might be very much interested in membership. We also include a dummy variable for native employees that takes on the value of 1 if the individual was born in the country analyzed. We do not have clear-cut theoretical priors in this case (and international results for race and nationality are quite mixed, see Schnabel 2003), but it might be interesting to see whether foreigners are as likely to be union members as native employees.

The second group of variables reflects some characteristics of the workplace that have been found to influence unionization in a number of studies (reviewed by Riley 1997 and Schnabel 2003). We include four dummy variables for establishment size intervals that are above our reference group of establishments with less than ten employees. We expect the probability of union membership to rise with establishment size because union costs of recruiting and organizing should be lower in larger units. In addition, union services may be valued most 
highly in large, bureaucratic organizations where workers are likely to be treated impersonally and feel a greater need for representation and protection. We also have information on whether there is a trade union at the workplace. If this is the case, it can be expected to increase an employee's likelihood of being a union member for at least three reasons: First, union representatives at the workplace have direct access to the employees, which facilitates recruiting efforts. Second, and related, union membership may be an experience good (Bryson and Gomez 2003). Third, there may be higher peer pressure to conform to a social custom of union membership. Finally, we have constructed an index reflecting employees' freedom or influence at work that increases with the amount of control an employee can exert on his working environment. ${ }^{11}$ We expect a negative relationship with unionization since employees that have more influence and freedom at work should have lesser need for collective voice.

Employees' political, social and religious attitudes form a third group of explanatory variables that have been found to be related to unionization in many studies (see the survey by Riley 1997). The ESS data contain information on the political orientation of respondents measured on an 11-point scale ranging from 0 for left to 10 for right. The socialist roots of the labour movement in many countries suggest that left-wing views should be associated with a higher probability of union membership (which would imply a negative coefficient of this variable in our estimations), but in other countries (parts of) union movements have different political affiliations, so that the outcome is really an empirical matter. Employees were also asked to express their satisfaction with the way things are handled at the workplace in the last 12 months on an 11-point scale ranging from 0 for extremely dissatisfied to 10 for extremely satisfied. According to frustrationaggression theory we should expect a negative coefficient of this variable since dissatisfied employees are assumed to have a stronger desire for unionization and may be more likely to unionize. A further question asked respondents whether they thought that employees needed strong trade unions to protect work conditions and wages, offering a 5-point scale of agreement. Since our (recoded) index rises with the extent of agreement, we expect a positive association with the probability of union membership. Although we have no clear-cut theoretical priors, we also include information on whether an employee is a member of a church in

11 In the ESS, employees were asked to assess (on an 11-point scale) the extent to which they are allowed to a) be flexible in working hours, b) decide how daily work is organized, c) influence the job environment, d) influence decisions about the work direction, and e) change work tasks. By simply summing up the answers to these five questions we constructed an index of freedom at the workplace that ranges from 0 (no influence) to 50 (complete control). 
order to see whether (and in which countries) religious attitudes are associated with unionization. ${ }^{12}$

The fourth and final group of variables is meant to reflect social factors such as the influence of reference groups and key individuals on the decision maker. Unfortunately the ESS data set does not contain information on whether an employee's spouse or his parents were union members or blue collar workers. There is, however, some information on the educational level achieved by the respondent's parents, so that we can construct two dummy variables taking on the value of 1 if the father or the mother has a low level of education. While these dummy variables should play no role in a purely economic reasoning, according to social custom theory and to the interactionist approach they can be expected to have a positive influence on the probability of union membership due to a unionfriendly socialization process in the family. The opposite might be the case, however, if the respondent's parents were self-employed. We take this into account by including a dummy variable that takes on the value of 1 if the father or the mother was self-employed when the respondent was 14 years old.

\section{(Table 2 about here)}

Table 2 presents the results of estimating identical models with the explanatory variables described above for all 18 countries. It concentrates on the signs of estimated coefficients that are statistically significant at the 5 (10) per cent level; detailed estimation results for all countries are documented in an Appendix Table. From Table 2 it can be seen that our model does not perform equally well in each country and that the same covariates have rather different explanatory power across countries (in some cases even changing signs between countries). This is not surprising given the substantial differences between countries concerning the labour movement, the political and social system, traditions and history, the stage of economic development and the current economic situation. Despite these differences some interesting insights about the importance of some (groups of) explanatory variables and their relevance in certain (groups of) countries can be obtained.

While it is not possible to discuss the significance or insignificance of each covariate in each country, it seems to be promising to look at the four groups of explanatory variables identified above and assess their relevance for explaining

12 For a recent comparative study analyzing the complex relationship between church attendance and union membership see Gomez, Lipset and Meltz (2001). 
union membership. Formally this is done by conducting Wald tests on the joint statistical significance of each group of variables in each country. The prob-values of these tests are presented in Table 3, and together with the significance of single variables reported in Table 2 they enable us to draw some conclusions on the (relative) importance of various characteristics.

(Table 3 about here)

From Table 3 it can be seen that personal characteristics play a significant role in explaining union membership in 12 of the 18 countries studied. The relative importance of individual characteristics, however, varies considerably between countries, and there is not one country in which all the personal characteristics included in the model prove to be significant (see Table 2). Usually the signs of the estimated coefficients are as expected, but in some countries males do not have a higher but a significantly lower probability of being a union member than females. Varying signs are also obtained for natives' probability of unionization.

Workplace characteristics are highly significant determinants of unionization in 16 of the 18 countries studied (and are weakly significant in a seventeenth country, see Table 3). The most important variable in this group and overall seems to be the presence of a trade union at the workplace which makes it easier to recruit, serve and keep members. In all 18 countries the probability of union membership is significantly higher if there is a union at the workplace (see Table 2). ${ }^{13}$ At first sight, the size of an establishment does not seem to play a role for unionization, which would be in stark contrast to previous findings. However, it can be assumed that due to scale effects in recruiting and organizing the presence of a union is not independent of establishment size. ${ }^{14}$ For each country we therefore estimated a second variant of the model excluding union presence at the workplace. The results are documented in the Appendix Table and they show that now establishment size plays a significant role in explaining membership in the majority of countries.

Employees' attitudes make a significant contribution to explaining union membership in 12 of the 18 countries studied. While a left-wing political

13 This finding is consistent with a number of previous cross-national studies using aggregate data that find positive effects of workplace representation (rights) on union density; see, e.g., Hancké (1993), Ebbinghaus and Visser (1999), Checchi and Visser (2001) and Checchi and Lucifora (2002).

14 A simple probit analysis not documented here shows that the probability of union presence at the workplace significantly increases with establishment size in each country. 
orientation, dissatisfaction with the way things are handled at work and being a church member significantly increase the probability of union membership in only a few countries, an individual's attitude towards strong unions proves to be significant in most countries. The stronger workers agree that employees need strong trade unions to protect work conditions and wages the more likely they are to be union members. An interesting exception to this rule is found in the former communist countries of eastern Europe (i.e. Hungary, Poland, Slovenia) where in the past unions used to be state-controlled mass organizations and where the labour movement is now often divided between anti-communist, post-communist and other unions.

Quite in contrast to the other groups of variables, the social factors included in our study do not play a significant role in explaining union membership in most countries (see Table 3). This result does not necessarily imply that social factors and social customs are not important for unionization. It may well reflect a lack of better data, since information on the union status of a respondent's spouse or parents and other likely determinants is not available in the ESS data set. The potential importance of family background and socialization is underscored by the result that in five countries the experience of self-employment of the father or the mother is associated with a more or less significant reduction in the probability of union membership (see Table 2).

In addition to these four groups of variables studied, institutional factors can influence unionization. A prominent example is the union-administered unemployment insurance found in Belgium, Denmark, Finland and Sweden, the so-called Ghent system, which may exert a positive influence on the recruitment and retention of union members. Empirical tests of this hypothesis have consistently found that the presence of a union-managed unemployment insurance is an important determinant of cross-national differences in union density (see, e.g., Western 1997, Ebbinghaus and Visser 1999, Blaschke 2000, Checchi and Lucifora 2002). While a formal test of this hypothesis is not possible with our data on individuals, Table 1 confirms that union density of employees in these four countries is among the highest in the European Union, ${ }^{15}$ and an additional descriptive analysis not reported here indicates that union density of the unemployed is by far the highest in the Ghent countries. The Appendix Table also shows that establishment size does not play a significant role for union membership in these four countries (even if the significant variable indicating the

15 To be more precise, Denmark, Sweden and Finland record the highest union densities while Belgium is ranked fifth, a little bit behind Slovenia. 
workplace presence of a union is removed). This could reflect the possibility that union recruiting is different is these countries where the administration of the unemployment insurance system by union officials may be a quasi-selective incentive for workers to become union members, and the regular contact with the union during spells of unemployment may induce them to stay in the union.

\section{SIMULATING THE IMPACT OF KEY VARIABLES}

Up to now our discussion has devolved on issues of the statistical significance of the estimated coefficients and the directional influence of the covariates. The probit estimations presented in Table 2 have identified two variables that seem to have an important and wide-spread effect on unionization in almost all EU countries, namely the presence of a union at the workplace and employees' attitudes concerning strong unions. Even more important than the statistical significance of these determinants may be their economic (and political) significance, i.e. the magnitude of their effects. Only if these two significant variables have a material impact on the probability of union membership, they can be used as strategic instruments by unions intending to increase their membership.

Unfortunately, the estimated coefficients from a probit model (or any other nonlinear model) cannot easily be used to make statements about the size of the ceteris paribus effect of a change in the value of an exogenous variable (such as the presence or absence of a union at the workplace) on the value of the endogenous variable. This is because the size of the effect depends on both the starting level of the exogenous variable under consideration and on the values of all other variables in the model (see Long and Freese 2001: 87ff.). One way to ease interpretation of the estimates is to compute the estimated values of the endogenous variable (the probability of being a union member) for a person with certain characteristics and then to simulate how a change in the value of one exogenous variable (such as a union being present or not at the workplace) changes the estimated probability. The results of such simulations for the two explanatory variables mentioned above are shown in Table 4.

(Table 4 about here)

As a point of reference, the first column in Table 4 presents the estimated probability of union membership for a hypothetical individual $A$ whose 
characteristics are set equal to the sample means of all the explanatory variables in the empirical model for the corresponding country. ${ }^{16}$ Leaving the values of the other explanatory variables unchanged, the next two columns illustrate the effects of union presence at the workplace by simulating the probability of being a union member for an individual B working in an establishment without unions and for a similar individual $\mathrm{C}$ who reports that there is a union at the workplace. The difference between the membership probabilities of individuals $B$ and $C$ can be interpreted as the effect of union presence at the workplace, ceteris paribus. To make just one example, the simulations show that in Austria the probability of being a union member increases from 9.7 to 44.4 per cent if there is a union at the workplace. Substantial effects of this sort are found in almost every country investigated, and they are particularly high in Ireland, Slovenia and the United Kingdom.

The last two columns illustrate the effects of individuals' attitudes towards unions by simulating the probability of being a union member for an individual $D$ who does not believe that employees need strong unions and for a similar individual $E$ who believes in strong unions. Again taking Austria as an example, the simulations show that the probability of being a union member increases from 4.0 to 45.2 per cent if an individual fully agrees that employees need strong unions. In the majority of countries similar effects of substantial magnitude are found. Taken together these simulations imply that it may be worthwhile for unions to strengthen their presence at the workplace and to positively influence public opinion towards unions.

\section{CONCLUSIONS}

Using representative individual-level data from the first round of the European Social Survey (ESS) fielded in 2002/03, this paper provided an empirical analysis of unionization in 18 countries of the European Union. We showed that union density varies considerably in Europe, ranging from almost 84 per cent in Denmark to just 11 per cent in Portugal. In most countries, individuals' probability of union membership is significantly affected by their personal characteristics, their attitudes and the characteristics of their workplace, whereas social factors seem to play a minor role.

16 It should be noted that these estimates differ from the union densities calculated in Table 1 because they are based on unweighted data and on a smaller number of cases (due to missing values in some of the explanatory variables). 
We identified the presence of a union at the workplace and employees' attitudes concerning strong unions as the two variables that have the most wide-spread (and also quite substantial) effects on the probability of being a union member. This implies that unions which want to grow should increase their presence at the workplace. In addition to such a recruitment strategy, a public relations strategy for improving employees' attitudes towards unions could also be helpful (although changing norms and attitudes is usually a very difficult and long-term task). Moreover, it may be no coincidence that the three countries with the highest union density (namely Denmark, Sweden and Finland) all have a union-administered unemployment insurance and that in these countries women's probability of union membership is higher than that of men. These observations point to further union recruitment strategies.

Our empirical findings do not enable us to discriminate between alternative (but often related) theories from economics and social psychology. For example, the impact of union presence at the workplace, the most important explanatory variable identified, is consistent with a traditional economic explanation (i.e. costbenefit considerations on the sides of employees and unions), with rational-choice theory, with an interactionist explanation and with social custom theory. We are also aware of the problem that cross-sectional analyses can only detect correlations between variables and are not able to answer questions of causality. While we have been able to identify some factors associated with differences in union density and the probability of union membership, there may be other relevant factors such as national traditions, the history and current shape of the labour movement or individuals' work life experience that could not be taken into account because they are difficult to measure or because corresponding data are not available.

Due to lack of data we also could not investigate the process of joining or leaving a union. For this and for some of the problems mentioned above, panel data would be helpful, but unfortunately the European Social Survey (which has been fielded again in 2004) is not constructed as a panel. Nevertheless future waves of this survey may be helpful to see whether union densities and their determinants converge over time between groups of countries (as found for western and eastern Germany by Schnabel and Wagner 2003) and whether aggregate union membership and density in the European Union continue to fall. 
Table 1: Percentage of union members among employees in EU countries, 2002/2003

\begin{tabular}{|c|c|c|c|c|c|}
\hline Country & All & Male & Female & Blue collar & White collar \\
\hline $\begin{array}{l}\text { Austria } \\
(\mathrm{N}=1.096)\end{array}$ & $\begin{array}{c}31.1 \\
{[28.3,33.8]}\end{array}$ & $\begin{array}{c}36.2 \\
{[32.2,40.3]}\end{array}$ & $\begin{array}{c}25.9 \\
{[22.3,29.5]}\end{array}$ & $\begin{array}{c}31.1 \\
{[25.1,37.2]}\end{array}$ & $\begin{array}{c}31.2 \\
{[28.1,34.3]}\end{array}$ \\
\hline $\begin{array}{l}\text { Belgium } \\
(\mathrm{N}=869)\end{array}$ & $\begin{array}{c}39.7 \\
{[36.4,43.0]}\end{array}$ & $\begin{array}{c}42.0 \\
{[37.6,46.3]}\end{array}$ & $\begin{array}{c}37.4 \\
{[32.3,42.4]}\end{array}$ & $\begin{array}{c}56.3 \\
{[50.2,62.4]}\end{array}$ & $\begin{array}{c}35.0 \\
{[31.0,39.0]}\end{array}$ \\
\hline $\begin{array}{l}\text { Denmark } \\
(\mathrm{N}=873)\end{array}$ & $\begin{array}{c}83.6 \\
{[81.2,86.1]}\end{array}$ & $\begin{array}{c}82.0 \\
{[78.3,85.6]}\end{array}$ & $\begin{array}{c}85.3 \\
{[81.9,88.6]}\end{array}$ & $\begin{array}{c}84.6 \\
{[80.2,86.3]}\end{array}$ & $\begin{array}{c}83.2 \\
{[80.2,88.9]}\end{array}$ \\
\hline $\begin{array}{l}\text { Finland } \\
(\mathrm{N}=921)\end{array}$ & $\begin{array}{c}68.9 \\
{[66.0,71.9]}\end{array}$ & $\begin{array}{c}63.4 \\
{[58.9,67.8]}\end{array}$ & $\begin{array}{c}74.4 \\
{[70.4,78.3]}\end{array}$ & $\begin{array}{c}68.5 \\
{[63.1,73.8]}\end{array}$ & $\begin{array}{c}69.2 \\
{[65.5,72.8]}\end{array}$ \\
\hline $\begin{array}{l}\text { France } \\
(\mathrm{N}=667)\end{array}$ & $\begin{array}{c}15.6 \\
{[12.9,18.4]}\end{array}$ & $\begin{array}{c}15.2 \\
{[11.3,19.2]}\end{array}$ & $\begin{array}{c}16.0 \\
{[12.1,19.9]}\end{array}$ & \multicolumn{2}{|c|}{$\begin{array}{c}\text { (information on occupation } \\
\text { not available) }\end{array}$} \\
\hline $\begin{array}{l}\text { Germany } \\
(\mathrm{N}=1.322)\end{array}$ & $\begin{array}{c}21.7 \\
{[19.5,24.0]}\end{array}$ & $\begin{array}{c}28.6 \\
{[25.2,32.0]}\end{array}$ & $\begin{array}{c}14.4 \\
{[11.7,17.2]}\end{array}$ & $\begin{array}{c}26.7 \\
{[22.3,31.0]}\end{array}$ & $\begin{array}{c}19.8 \\
{[17.2,22.5]}\end{array}$ \\
\hline $\begin{array}{l}\text { Greece } \\
(\mathrm{N}=628)\end{array}$ & $\begin{array}{c}12.4 \\
{[9.8,15.0]}\end{array}$ & $\begin{array}{c}12.9 \\
{[9.4,16.4]}\end{array}$ & $\begin{array}{c}11.8 \\
{[7.9,15.6]}\end{array}$ & $\begin{array}{c}8.6 \\
{[4.9,12.4]}\end{array}$ & $\begin{array}{c}14.4 \\
{[11.0,17.9]}\end{array}$ \\
\hline $\begin{array}{l}\text { Hungary } \\
(\mathrm{N}=607)\end{array}$ & $\begin{array}{c}13.1 \\
{[10.3,15.7]}\end{array}$ & $\begin{array}{c}11.0 \\
{[7.6,14.5]}\end{array}$ & $\begin{array}{c}15.2 \\
{[11.0,19.3]}\end{array}$ & $\begin{array}{c}10.5 \\
{[6.7,14.2]}\end{array}$ & $\begin{array}{c}14.8 \\
{[11.0,18.6]}\end{array}$ \\
\hline $\begin{array}{l}\text { Ireland } \\
(\mathrm{N}=888)\end{array}$ & $\begin{array}{c}37.6 \\
{[34.5,40.8]}\end{array}$ & $\begin{array}{c}43.6 \\
{[38.9,48.4]}\end{array}$ & $\begin{array}{c}32.3 \\
{[28.0,36.6]}\end{array}$ & $\begin{array}{c}45.2 \\
{[38.6,51.7]}\end{array}$ & $\begin{array}{c}35.2 \\
{[31.5,38.9]}\end{array}$ \\
\hline $\begin{array}{l}\text { Italy } \\
(\mathrm{N}=410)\end{array}$ & $\begin{array}{c}18.2 \\
{[14.0,21.6]}\end{array}$ & $\begin{array}{c}22.9 \\
{[17.0,28.7]}\end{array}$ & $\begin{array}{c}13.8 \\
{[9.1,18.6]}\end{array}$ & $\begin{array}{c}17.9 \\
{[11.1,24.7]}\end{array}$ & $\begin{array}{c}19.2 \\
{[14.5,24.0]}\end{array}$ \\
\hline $\begin{array}{l}\text { Luxembourg } \\
(\mathrm{N}=591)\end{array}$ & $\begin{array}{c}34.8 \\
{[30.9,38.6]}\end{array}$ & $\begin{array}{c}40.9 \\
{[35.6,46.2]}\end{array}$ & $\begin{array}{c}27.2 \\
{[21.7,32.7]}\end{array}$ & $\begin{array}{c}44.6 \\
{[37.1,52.0]}\end{array}$ & $\begin{array}{c}31.1 \\
{[26.5,35.6]}\end{array}$ \\
\hline $\begin{array}{l}\text { Netherlands } \\
(\mathrm{N}=1.215)\end{array}$ & $\begin{array}{c}28.6 \\
{[26.1,31.2]}\end{array}$ & $\begin{array}{c}32.5 \\
{[28.8,36.3]}\end{array}$ & $\begin{array}{c}24.7 \\
{[21.3,28.2]}\end{array}$ & $\begin{array}{c}29.9 \\
{[24.0,35.7]}\end{array}$ & $\begin{array}{c}28.2 \\
{[25.4,31.0]}\end{array}$ \\
\hline $\begin{array}{l}\text { Poland } \\
(\mathrm{N}=694)\end{array}$ & $\begin{array}{c}15.7 \\
{[13.0,18.5]}\end{array}$ & $\begin{array}{c}13.8 \\
{[10.3,17.3]}\end{array}$ & $\begin{array}{c}18.3 \\
{[13.9,22.6]}\end{array}$ & $\begin{array}{c}17.4 \\
{[12.8,22.0]}\end{array}$ & $\begin{array}{c}14.7 \\
{[11.3,18.0]}\end{array}$ \\
\hline $\begin{array}{l}\text { Portugal } \\
(\mathrm{N}=594)\end{array}$ & $\begin{array}{c}11.1 \\
{[8.6,13.7]}\end{array}$ & $\begin{array}{c}12.3 \\
{[8.3,16.4]}\end{array}$ & $\begin{array}{c}10.1 \\
{[6.8,13.3]}\end{array}$ & $\begin{array}{c}8.6 \\
{[5.2,12.0]}\end{array}$ & $\begin{array}{c}14.0 \\
{[10.2,17.8]}\end{array}$ \\
\hline $\begin{array}{l}\text { Slovenia } \\
(\mathrm{N}=1.096)\end{array}$ & $\begin{array}{c}41.2 \\
{[37.5,45.0]}\end{array}$ & $\begin{array}{c}37.7 \\
{[32.5,42.9]}\end{array}$ & $\begin{array}{c}44.8 \\
{[39.4,50.2]}\end{array}$ & $\begin{array}{c}42.9 \\
{[36.3,49.4]}\end{array}$ & $\begin{array}{c}40.5 \\
{[35.8,45.1]}\end{array}$ \\
\hline $\begin{array}{l}\text { Spain } \\
(N=619)\end{array}$ & $\begin{array}{c}11.3 \\
{[8.8,13.7]}\end{array}$ & $\begin{array}{c}12.9 \\
{[9.4,16.4]}\end{array}$ & $\begin{array}{c}8.9 \\
{[5.4,12.4]}\end{array}$ & $\begin{array}{c}10.3 \\
{[6.3,13.8]}\end{array}$ & $\begin{array}{c}12.2 \\
{[8.8,15.6]}\end{array}$ \\
\hline $\begin{array}{l}\text { Sweden } \\
(\mathrm{N}=1.102)\end{array}$ & $\begin{array}{c}76.8 \\
{[74.3,79.3]}\end{array}$ & $\begin{array}{c}74.0 \\
{[70.4,77.6]}\end{array}$ & $\begin{array}{c}79.8 \\
{[76.3,83.2]}\end{array}$ & $\begin{array}{c}80.0 \\
{[75.2,84.8]}\end{array}$ & $\begin{array}{c}75.7 \\
{[72.8,78.6]}\end{array}$ \\
\hline $\begin{array}{l}\text { United King- } \\
\text { dom }(\mathrm{N}=984)\end{array}$ & $\begin{array}{c}26.6 \\
{[23.8,29.4]}\end{array}$ & $\begin{array}{c}26.3 \\
{[22.3,30.3]}\end{array}$ & $\begin{array}{c}26.8 \\
{[23.0,30.7]}\end{array}$ & $\begin{array}{c}24.5 \\
{[19.2,29.8]}\end{array}$ & $\begin{array}{c}27.4 \\
{[24.1,30.6]}\end{array}$ \\
\hline
\end{tabular}

Source: Own computations based on data from the European Social Survey 2002/2003 (ESS1e05, released June $17^{\text {th }}, 2004$ )

Note: $\quad \mathrm{N}=$ sample size used to calculate the figures reported in the column "All"; computations use weighted data; $95 \%$ confidence intervals reported in brackets. The samples include all respondents aged 15 to 64 who were employed (and neither self-employed nor in paid work) at the time interview. White collar workers are defined following the ILO International Standard Classification of Occupation (ISCO-88) as those with ISCO Nos. $<7000$, blue collar workers as those with $7000 \leq$ ISCO $\leq 9999$. 
Table 2: Factors influencing the probability of union membership in 18 EU countries (results of the probit analyses documented in the Appendix Table)

\begin{tabular}{|c|c|c|c|c|c|c|c|c|c|c|}
\hline Variables & $\begin{array}{l}\text { expected } \\
\text { sign }\end{array}$ & Austria & $\begin{array}{l}\text { Bel- } \\
\text { gium }\end{array}$ & $\begin{array}{l}\text { Den- } \\
\text { mark }\end{array}$ & $\begin{array}{l}\text { Fin- } \\
\text { land }\end{array}$ & France & $\begin{array}{l}\text { Ger- } \\
\text { many }\end{array}$ & Greece & $\begin{array}{l}\text { Hun- } \\
\text { gary }\end{array}$ & $\begin{array}{l}\text { Ire- } \\
\text { land }\end{array}$ \\
\hline $\begin{array}{l}\text { personal characteristics: } \\
\text { gender (male }=1 \text { ) } \\
\text { age (in years) } \\
\text { age squared } \\
\text { low education (below upper } \\
\text { secondary }=1 \text { ) } \\
\text { high education (second stage } \\
\text { of tertiary }=1 \text { ) } \\
\text { native (born in country = } 1 \text { ) } \\
\text { full-time worker }(1=\text { yes) } \\
\text { blue-collar worker }(1=\text { yes) }\end{array}$ & $\begin{array}{l}+ \\
+ \\
- \\
- \\
- \\
? \\
+ \\
+ \\
+\end{array}$ & & $\begin{array}{l}- \\
+ \\
+ \\
+\end{array}$ & $\begin{array}{l}- \\
+ \\
- \\
-\end{array}$ & $\begin{array}{l}- \\
+ \\
-\end{array}$ & $(+)$ & $\begin{array}{l}+ \\
\\
(+) \\
\end{array}$ & - & $\begin{array}{c}(-) \\
- \\
(+)\end{array}$ & + \\
\hline $\begin{array}{l}\text { workplace characteristics: } \\
\text { establishment size } \\
\text { (intervals) } \\
\text { - } 10 \text { to } 24 \text { employees } \\
\text { - } 25 \text { to } 99 \text { employees } \\
\text { - } 100 \text { to } 499 \text { employees } \\
\text { - } 500 \text { or more employees } \\
\text { union at workplace ( } 1 \text { = yes) } \\
\text { extent of freedom at work } \\
\text { (index: from } 0 \text { to } 50 \text { ) }\end{array}$ & $\begin{array}{l}+ \\
+ \\
+ \\
+ \\
+ \\
+ \\
-\end{array}$ & + & $(+)$ & + & + & + & + & $\begin{array}{l}+ \\
+ \\
+ \\
\end{array}$ & + & + \\
\hline $\begin{array}{l}\text { attitudes: } \\
\text { political orientation } \\
\text { (index: } 0=\text { left, } 10=\text { right) } \\
\text { satisfaction with way things } \\
\text { are handled at work (index) } \\
\text { agree that employees need } \\
\text { strong unions (index) } \\
\text { member of a church ( } 1=\text { yes) }\end{array}$ & $\begin{array}{l}- \\
- \\
+ \\
?\end{array}$ & $\begin{array}{l}+ \\
(+)\end{array}$ & + & + & $\begin{array}{l}+ \\
+\end{array}$ & + & + & & $(+)$ & $\begin{array}{l}- \\
+ \\
+\end{array}$ \\
\hline $\begin{array}{l}\text { social factors: } \\
\text { father's level of education } \\
\text { (low }=1) \\
\text { mother's level of education } \\
\text { (low }=1 \text { ) } \\
\text { father and/or mother self- } \\
\text { employed when respondent } \\
\text { was } 14 \text { years old ( } 1=\text { yes) }\end{array}$ & $\begin{array}{l}+ \\
+ \\
-\end{array}$ & - & & & + & & & $(+)$ & & \\
\hline
\end{tabular}

Note: The signs reported reflect those of the estimated coefficients that are statistically significant at the 5 per cent level or better; signs in bracket reflect a significance level of 10 per cent. 
Table 2 (continued)

\begin{tabular}{|c|c|c|c|c|c|c|c|c|c|c|}
\hline Variables & $\begin{array}{l}\text { expected } \\
\text { sign }\end{array}$ & Italy & $\begin{array}{l}\text { Luxem- } \\
\text { bourg }\end{array}$ & $\begin{array}{l}\text { Nether- } \\
\text { lands }\end{array}$ & Poland & $\begin{array}{l}\text { Portu- } \\
\text { gal }\end{array}$ & $\begin{array}{l}\text { Slo- } \\
\text { venia }\end{array}$ & $\begin{array}{l}\text { Spai } \\
\mathrm{n}\end{array}$ & $\begin{array}{l}\text { Swe- } \\
\text { den }\end{array}$ & UK \\
\hline \multicolumn{11}{|l|}{ personal characteristics: } \\
\hline gender $($ male $=1)$ & + & + & & & $(-)$ & & - & & - & $(+)$ \\
\hline age (in years) & + & & & $(+)$ & + & & & & + & \\
\hline age squared & - & & & & - & & & & & \\
\hline $\begin{array}{l}\text { low education (below upper } \\
\text { secondary }=1 \text { ) }\end{array}$ & - & & - & & & & & & & - \\
\hline $\begin{array}{l}\text { high education (second } \\
\text { stage of territory }=1 \text { ) }\end{array}$ & - & & $(-)$ & & & & - & & & \\
\hline native (born in country $=1$ ) & $?$ & $(-)$ & & & - & + & & & & \\
\hline full-time worker (1 = yes) & + & & & & & & & & + & $(+)$ \\
\hline blue-collar worker ( 1 = yes) & + & & & + & & & & & & \\
\hline \multicolumn{11}{|l|}{$\begin{array}{l}\text { workplace } \\
\text { characteristics: }\end{array}$} \\
\hline \multicolumn{11}{|l|}{$\begin{array}{l}\text { establishment size } \\
\text { (intervals) }\end{array}$} \\
\hline $\begin{array}{l}\text { - } 10 \text { to } 24 \text { employees } \\
\text { - } 25 \text { to } 99 \text { employees } \\
\text { - } 100 \text { to } 499 \text { employees } \\
\text { - } 500 \text { or more employees }\end{array}$ & $\begin{array}{l}+ \\
+ \\
+ \\
+\end{array}$ & $\begin{array}{l}+ \\
(+) \\
+\end{array}$ & & & & & & & & \\
\hline $\begin{array}{l}\text { union at workplace }(1= \\
\text { yes })\end{array}$ & + & + & + & + & + & $\begin{array}{l}+ \\
+\end{array}$ & + & + & + & + \\
\hline $\begin{array}{l}\text { extent of freedom at work } \\
\text { (index: from } 0 \text { to } 50 \text { ) }\end{array}$ & - & & - & & & & & & & \\
\hline \multicolumn{11}{|l|}{ attitudes: } \\
\hline $\begin{array}{l}\text { political orientation } \\
\text { (index: } 0=\text { left, } 10=\text { right) }\end{array}$ & - & & - & & & & & & & \\
\hline $\begin{array}{l}\text { satisfaction with way things } \\
\text { are handled at work (index) }\end{array}$ & - & & & & & & & - & $(-)$ & \\
\hline $\begin{array}{l}\text { agree that employees need } \\
\text { strong unions (index) }\end{array}$ & + & + & & + & & $(+)$ & & + & + & + \\
\hline $\begin{array}{l}\text { member of a church }(1= \\
\text { yes) }\end{array}$ & $?$ & & & & + & & & & & \\
\hline \multicolumn{11}{|l|}{ social factors: } \\
\hline $\begin{array}{l}\text { father's level of education } \\
(\text { low }=1)\end{array}$ & + & & & & & & $(+)$ & & + & \\
\hline $\begin{array}{l}\text { mother's level of education } \\
(\text { low = 1) }\end{array}$ & + & & & & & $(-)$ & & & & \\
\hline $\begin{array}{l}\text { father and/or mother self- } \\
\text { employed when respondent } \\
\text { was } 14 \text { years old }(1=\text { yes) }\end{array}$ & - & & $(-)$ & - & & & $(-)$ & & & - \\
\hline
\end{tabular}


Table 3: Significance of groups of variables in explaining union membership

\begin{tabular}{|c|c|c|c|c|}
\hline Country & $\begin{array}{c}\text { Personal } \\
\text { characteristics }\end{array}$ & $\begin{array}{c}\text { Workplace } \\
\text { characteristics }\end{array}$ & Attitudes & $\begin{array}{l}\text { Social } \\
\text { factors }\end{array}$ \\
\hline Austria & 0.314 & $0.000^{* *}$ & $0.000^{* *}$ & 0.113 \\
\hline Belgium & $0.000^{* *}$ & 0.306 & $0.000^{* *}$ & 0.836 \\
\hline Denmark & $0.000^{* *}$ & 0.077 & $0.000^{* *}$ & 0.593 \\
\hline Finland & $0.005^{* *}$ & $0.012^{*}$ & $0.001^{* *}$ & 0.150 \\
\hline France & $0.001^{* *}$ & $0.000^{* *}$ & $0.000^{* *}$ & 0.468 \\
\hline Germany & $0.000^{* *}$ & $0.000^{* *}$ & $0.000^{* *}$ & 0.560 \\
\hline Greece & 0.116 & $0.000^{* *}$ & 0.440 & 0.130 \\
\hline Hungary & $0.041^{*}$ & $0.000^{* *}$ & 0.535 & 0.236 \\
\hline Ireland & 0.105 & $0.000^{* *}$ & $0.000^{* *}$ & 0.693 \\
\hline Italy & 0.095 & $0.002^{* *}$ & 0.179 & 0.448 \\
\hline Luxembourg & $0.007^{* *}$ & $0.001^{* *}$ & 0.108 & 0.314 \\
\hline Netherlands & $0.000^{* *}$ & $0.000^{* *}$ & $0.000^{* *}$ & $0.035^{*}$ \\
\hline Poland & $0.000^{* *}$ & $0.000^{* *}$ & $0.000^{* *}$ & 0.460 \\
\hline Portugal & 0.153 & $0.000^{* *}$ & 0.074 & 0.303 \\
\hline Slovenia & $0.004^{* *}$ & $0.000^{* *}$ & 0.323 & 0.079 \\
\hline Spain & 0.299 & $0.000^{* *}$ & $0.004^{* *}$ & 0.856 \\
\hline Sweden & $0.000 * *$ & $0.000^{* *}$ & $0.000^{* *}$ & $0.002^{* *}$ \\
\hline $\begin{array}{l}\text { United } \\
\text { Kingdom }\end{array}$ & $0.000^{* *}$ & $0.000^{* *}$ & $0.000^{* *}$ & 0.077 \\
\hline
\end{tabular}

Source: Own computations based on data from the European Social Survey 2002/2003 (ESS1e05, released June $17^{\text {th }}, 2004$ ) and on the regression models in Table 2 and in the Appendix Table.

Note: Reported values are prob-values from Wald tests for the joint significance of variables in a group; if a prob-value is $0.050(0.010)$ or less, the null hypothesis that the variables in the group have no impact on the probability of union membership is rejected at an error level of 5 (1) per cent or smaller; for a quick look, $\left.{ }^{*}{ }^{* *}\right)$ denotes statistical significance at the 5 (1) per cent level. 
Table 4: Simulated probabilities of union membership for various individuals

\begin{tabular}{|c|c|c|c|c|c|}
\hline Country & $A$ & $\mathrm{~B}$ & C & $D$ & $E$ \\
\hline Austria & 28.2 & 9.7 & 44.4 & 4.0 & 45.2 \\
\hline Belgium & 43.8 & (37.5) & $(47.3)$ & 18.9 & 57.1 \\
\hline Denmark & 90.3 & 85.0 & 92.3 & 74.5 & 94.3 \\
\hline Finland & 72.6 & 59.2 & 75.0 & 54.2 & 77.0 \\
\hline France & 7.2 & 0.5 & 17.1 & 0.3 & 19.6 \\
\hline Germany & 17.8 & 6.9 & 35.2 & 3.9 & 30.5 \\
\hline Greece & 6.1 & 1.0 & 23.4 & $(5.0)$ & $(6.3)$ \\
\hline Hungary & 3.4 & 0.1 & 32.5 & $(1.9)$ & $(3.9)$ \\
\hline Ireland & 28.8 & 3.3 & 67.6 & 8.3 & 41.4 \\
\hline Italy & 15.0 & 5.1 & 22.3 & 3.3 & 21.2 \\
\hline Luxembourg & 37.3 & 25.3 & 45.7 & $(30.0)$ & $(40.0)$ \\
\hline Netherlands & 28.1 & 4.2 & 37.5 & 7.2 & 43.0 \\
\hline Poland & 3.8 & 0.2 & 32.8 & $(2.1)$ & $(4.6)$ \\
\hline Portugal & 5.8 & 2.2 & 19.2 & $(1.0)$ & $(8.7)$ \\
\hline Slovenia & 38.7 & 5.9 & 57.5 & $(30.7)$ & $(40.7)$ \\
\hline Spain & 8.0 & 3.0 & 20.6 & 0.4 & 14.1 \\
\hline Sweden & 85.0 & 63.9 & 87.4 & 41.5 & 93.4 \\
\hline United Kingdom & 19.0 & 3.7 & 53.1 & 3.0 & 36.4 \\
\hline
\end{tabular}

Source: Own computations based on data from the European Social Survey 2002/2003 (ESS1e05, released June $17^{\text {th }}, 2004$ ) and on the regression models in Table 2 and in the Appendix Table.

Note: Reported values are the estimated probabilities of union membership (in per cent) of five hypothetical individuals $A$ to $E$ with the following varying characteristics:

Individual $A$ : an employee for whom the values of the explanatory variables in the union membership function are set equal to the mean of the sample used for each country. Individual B: same as A but working in an establishment where there is no union at the workplace

Individual C: same as A but working in an establishment where there is a union at the workplace

Individual D: same as A but disagrees strongly that employees need strong unions Individual E: same as A but agrees strongly that employees need strong unions.

Values are put in brackets if the estimated coefficient of the explanatory variable used for the simulations $\mathrm{B} / \mathrm{C}$ or $\mathrm{D} / \mathrm{E}$ is not statistically significant at the 5 per cent level or better (see Table 2). 


\section{REFERENCES}

Akerlof, George A. (1980): A Theory of Social Custom, of Which Unemployment May Be One Consequence, Quarterly Journal of Economics, 95, 749-775.

Berkowitz, Monroe (1954): The Economics of Trade Union Organization and Administration, Industrial and Labor Relations Review, 7, 537-549.

Beyme, Klaus von (1981): Challenge to Power: Trade Unions and Industrial Relations in Capitalist Countries, London.

Blaschke, Sabine (2000): Union Density and European Integration, European Journal of Industrial Relations, 6, 217-236.

Booth, Alison L. (1985): The Free Rider Problem and a Social Custom Model of Trade Union Membership, Quarterly Journal of Economics, 100, 253-261.

Booth, Alison L. / Chatterji, Monojit (1993): Reputation, Membership and Wages in an Open Shop Trade Union, Oxford Economic Papers, 45, 23-41.

Booth, Alison L. / Chatterji, Monojit (1995): Union Membership and Wage Bargaining when Membership is not compulsory, Economic Journal, 105, 345-360.

Bryson, Alex / Gomez, Rafael (2003): Buying into Union Membership, in: Gospel, Howard / Wood, Stephen (eds.), Representing Workers - Trade Union Recognition and Membership in Britain, London, 72-91.

Bryson, Alex / Gomez, Rafael / Gunderson, Morley / Meltz, Noah (2005): YouthAdult Differences in the Demand for Unionisation: Are American, British, and Canadian Workers All That Different?, Journal of Labor Research, 26, 155167.

Bulkley, George / Myles, Gareth D. (2001): Individually rational union membership, European Journal of Political Economy, 17, 117-137.

Calmfors, Lars / Booth, Alison / Burda, Michael / Checci, Daniele / Naylor, Robin / Visser, Jelle (2001): The Future of Collective Bargaining in Europe, in: Boeri, Tito / Brugiavini, Agar / Calmfors, Lars (eds.), The Role of Unions in the Twenty-First Century, Oxford, 1-155.

Chaison, Gary N. / Rose, Joseph B. (1991): The Macrodeterminants of Union Growth and Decline, in: Strauss, George / Gallagher, Daniel G. / Fiorito, Jack (eds.), The State of the Unions, Madison, WI, 3-45.

Checchi, Daniele / Lucifora, Claudio (2002): Unions and labour market institutions in Europe, Economic Policy, 35, 362-408.

Checchi, Daniele / Visser, Jelle (2001): Pattern Persistence in European Trade Union Density, AIAS Working Paper 01_04, University of Amsterdam (forthcoming 2005 in European Sociological Review).

Corneo, Giacomo (1995): Social custom, management opposition, and trade union membership, European Economic Review, 39, 275-292.

Crouch, Colin (1982): Trade Unions: the Logic of Collective Action, Glasgow. 
Ebbinghaus, Bernhard / Visser, Jelle (1999): When Institutions Matter - Union Growth and Decline in Western Europe, 1950-1995, European Sociological Review, 15, 135-158.

Frege, Carola M. (1996): Union Membership in Post-Socialist East Germany: Who Participates in Collective Action?, British Journal of Industrial Relations, 34, 387-413.

Gomez, Rafael / Lipset, Seymour M. / Meltz, Noah (2001): Religiosity and Unionisation: A Cross-Country Comparison, paper presented at the 2001 SASE Conference, University of Amsterdam, June 29, 2001.

Guest, David E. / Dewe, Philip (1988): Why Do Workers Belong to a Trade Union? A Social Psychological Study in the UK Electronics Industry, British Journal of Industrial Relations, 26, 178-194.

Hancké, Bob (1993): Trade Union Membership in Europe, 1960-1990: Rediscovering Local Unions, British Journal of Industrial Relations, 31, 593613.

Jones, Stephen R. G. I McKenna, C. J. (1994): A Dynamic Model of Union Membership and Employment, Economica, 61, 179-189.

Jowell, Roger and the Central Co-ordinating Team (2003): European Social Survey 2002/2003: Technical Report, London: Centre for Comparative Social Surveys, City University.

Kelley, Harold H. / Michela, John L. (1980): Attribution Theory and Research, Annual Review of Psychology, 31, 457-501.

Klandermans, Bert (1984): Mobilization and Participation: Social-Psychological Expansions of Resource Mobilization Theory, American Sociological Review, 49, 583-600.

Klandermans, Bert (1986): Psychology and trade union participation: Joining, acting, quitting, Journal of Occupational Psychology, 59, 189-204.

Lesch, Hagen (2004): Gewerkschaftlicher Organisationsgrad im internationalen Vergleich, iw-trends, 31/2, 5-15.

Long, J. Scott / Freese, Jeremy (2001): Regression Models for Categorical Dependent Variables using Stata, College Station, TX.

Moreton, David (1998): An open shop trade union model of wages, effort and membership, European Journal of Political Economy, 14, 511-527.

Naylor, Robin A. (1990): A Social Custom Model of Collective Action, European Journal of Political Economy, 6, 201-216.

Naylor, Robin / Cripps, Martin (1993): An economic theory of the open shop trade union, European Economic Review, 37, 1599-1620.

Naylor, Robin / Raaum, Odbjørn (1993): The Open Shop Union, Wages and Management Opposition, Oxford Economic Papers, 45, 589-604.

Olson, Mancur (1965): The Logic of Collective Action, Cambridge, Mass.

Pencavel, John H. (1971): The Demand for Union Services: An Exercise, Industrial and Labor Relations Review, 24, 180-190.

Riley, Nicola-Maria (1997): Determinants of Union Membership: A Review, Labour, $11,265-301$. 
Schelling, Thomas C. (1978): The Micromotives of Macrobehaviour, New York.

Schnabel, Claus (2003): Determinants of trade union membership, in: Addison, John T. I Schnabel, Claus (eds.), International Handbook of Trade Unions, Cheltenham, 13-43.

Schnabel, Claus / Wagner, Joachim (2003): Trade Union Membership in Eastern and Western Germany: Convergence or Divergence?, Applied Economics Quarterly, 49, 213-232.

Streeck, Wolfgang (1981): Gewerkschaftliche Organisationsprobleme in der sozialstaatlichen Demokratie, Königstein, Ts.

Tajfel, Henri (ed.) (1982): Social Identity and Intergroup Relations, Cambridge.

Visser, Jelle (2002): Why Fewer Workers Join Unions in Europe, British Journal of Industrial Relations, 40, 403-430.

Visser, Jelle (2003): Unions and Unionism around the World, in: Addison, John T. I Schnabel, Claus (eds.), International Handbook of Trade Unions, Cheltenham, 366-413.

Western, Bruce (1997): Between Class and Market - Postwar Unionization in the Capitalist Democracies, Princeton.

Wheeler, Hoyt N. / McClendon, John A. (1991): The Individual Decision to Unionize, in: Strauss, George / Gallagher, Daniel G. / Fiorito, Jack (eds.), The State of the Unions, Madison, WI, 47-83. 

